\title{
PALAEOXYLOTOMICAL STUDY OF A NEW COLLECTION FROM ZARAND MIOCENE PETRIFIED FOREST, SOUTH APUSENI MTS.
}

\author{
Stănilă Iamandei ${ }^{*}$, Eugenia Iamandei ${ }^{1}$ \& Petru Todea ${ }^{2}$
}

Received: 09 August 2019 / Accepted: 14 October 2019 / Published online: 25 October 2019

\begin{abstract}
We had in study some samples from a private collection of petrified wood, from South Apuseni mts., found in an area where numerous Miocene petrified woods were already described and tens lignotaxa were identified. These new petrified woods were collected from Ociu area, on the Church's brook. They could contribute to better knowing that fabulous Mid-Miocene forest, and by palaeoxylotomic study the following arboreal taxa were identified: Thujoxylon sp., Magnolioxylon kräuselii (Greguss) Van der Burgh, Spiroplatanoxylon densiradiatum (Petrescu) Süss, and Quercoxylon sp. cf. Quercus frainetto Tenore.
\end{abstract}

Keywords: South Apuseni mts., Zarand Petrified Forest, Todea Collection, Miocene taxa.

\section{INTRODUCTION}

"Todea Collection" is a private collection of petrified wood, initially gathered simply by curiosity, from some areas with occurrences of silicifications often as colored opals, related to volcanic rocks, otherwise common and known in some points of South Apuseni mountains. The idea of their study captivated us, hoping that those beautiful samples, hosted now home by one of the authors of the present paper, would be donated to the "Gold Museum" of Brad town. The here studied specimens were collected from Mid-Miocene deposits from Ociu locality, Bisericii brook (i.e Church's brook), in Prăvăleni-Ociu area, South Apuseni mts., where a Zarand Miocene Petrified Forest is already outlined by previous studies (see Fig. 1 in Iamandei \& Iamandei, 2017).

The composition of that fossil forest was revealed by the study of numerous petrified wood remains collected from those fossiliferous sites, the list of the identified lignotaxa comprising more than 30 species of Conifers, Angiosperms - Dicots and Monocots. By the study of six samples of petrified wood from "Todea Collection" we have identified the following taxa: Thujoxylon sp., Magnolioxylon kräuselii (Greguss) Van der Burgh, Spiroplatanoxylon densiradiatum (Petrescu) Süss, and Quercoxylon sp. cf. Quercus frainetto Ten.

\section{PALEOXYLOTOMY}

Family Cupressaceae Gray, 1822, nom. cons. (sensu Farjon, 2005)

Subfamily Cupressoideae Rich. ex Sweet,1826

Genus Thujoxylon Unger, 1847

Thujoxylon sp.

Fig. 1, a-i; Fig. 2, a-i.

\section{Material}

Two samples of petrified wood collected from South Apuseni mts., Ociu area, Bisericii brook, from MidMiocene deposits (late Badenian-early Sarmatian), kept now in "Todea Collection", in Crișcior-Brad locality, under the indicative OB-4 and OB-5, both with standard oriented thin sections prepared, were submitted to the paleoxylotomical study.

\section{Microscopic description}

The growth rings are relatively wide, of 36-60 cells, with distinct boundaries, since the late wood is represented by 5-7 tangential rows of radially flattened and thick-walled cells, disperse few parenchyma cells often with black content. Normal resin canals are absent.

The tracheids, in the early-wood, are big, quadrangular or polygonal shaped, or slightly elongate, and are relatively thin-walled (4-6 $\mu \mathrm{m}$ the double wall). Their lumina have slightly rounded corners, and radial / tangential diameters of 25-35 / 20-30 $\mu \mathrm{m}$, gradually diminishing through transitional 6-8 tangential rows of smaller lumened cells to the latewood, where they appear in 8-12 tangential rows of small, quadrangular, radially crushed and very thickwalled cells, of 8-12 $\mu \mathrm{m}$ double wall, and with $\mathrm{r} / \mathrm{tg}$ diameters of $10-15 / 8-15 \mu \mathrm{m}$. There are 1-9 radial rows between two rays and the density is of 1900-2025 tracheids on sq. mm. The tangential tracheidal walls seem to be pitted, with small and spaced pits. The radial abietineous pitting is uniseriate, spaced or nearly contiguous and probably with crassulae, difficult to see due to bad preservation. The bordered pits are relatively small (8-12 $\mu \mathrm{m}$ the diameter), with round aperture, of 3-5 $\mu \mathrm{m}$ in diameter.

The axial parenchyma seems to be absent, or rare, or difficult to observe in cross-section, since is quite similar to the tracheids. However, it is obvious in tangential view, having horizontal nodular walls, and presenting glomeruli of resin inside, or plugs with round concavities.

The rays are uniseriate, not too high, of up to 8-12 cells. Radially the rays seem to be homogeneous and are constituted from cells of 12-14 $\mu \mathrm{m}$ taller marginals and with waved outer walls. No details on the inclined walls have been observed. Indentures probably present, difficult to observe due to bad preservation. In the cross-fields, 1-2 small round to oval, small, badly preserved cupressoid or 

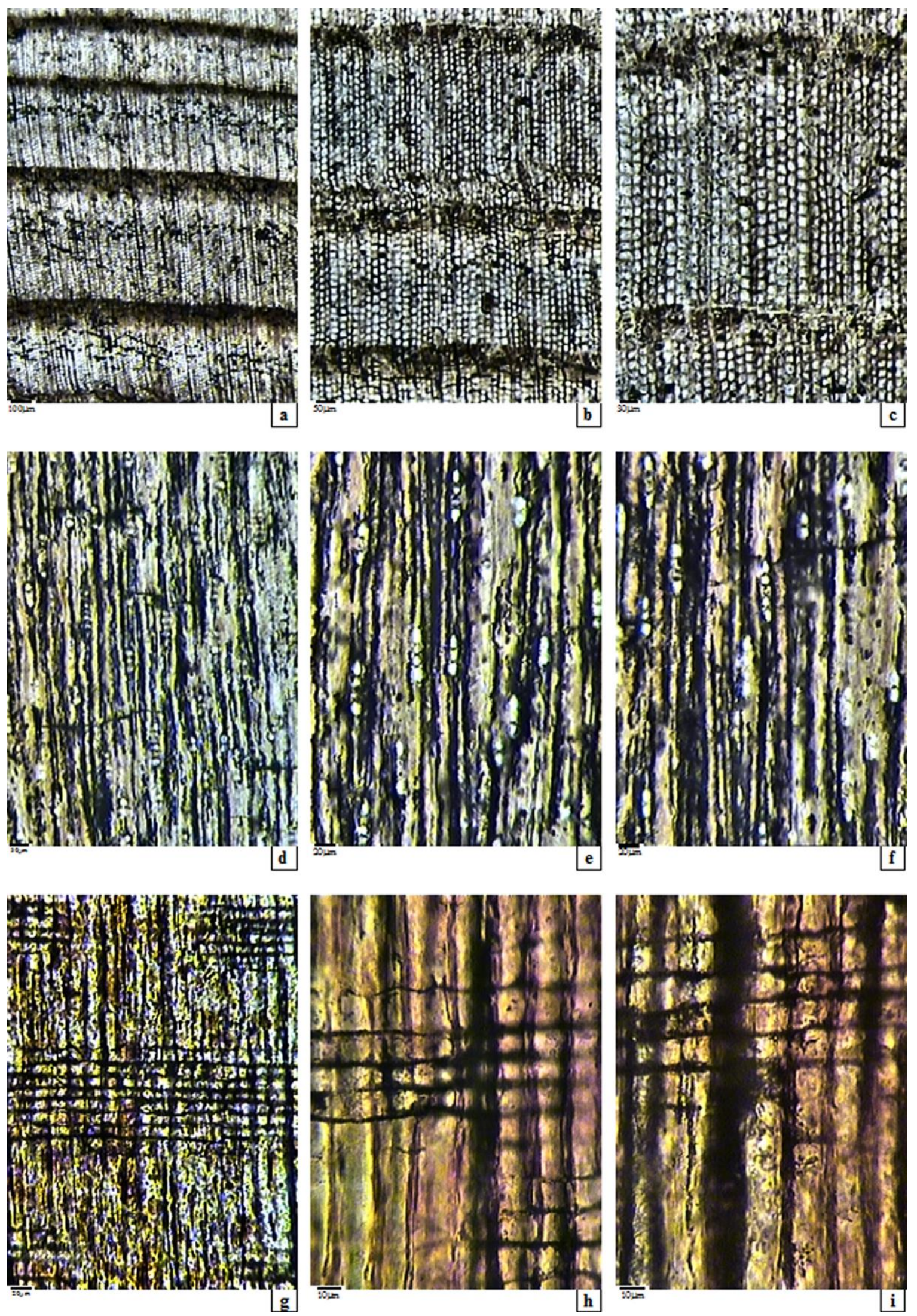

Fig. 1 a-i (graphic scale, $\mu \mathrm{m}$ ). Thujoxylon sp., Ociu, Bisericii brook, South Apuseni, Romania, sample OB-4. a-c. (cross section) - distinct growth rings, earlywood and latewood tracheids, few parenchyma dispersed, uniseriate rays; d-f. (tangential section) - uniseriate short rays, parenchyma with nodular horizontal walls and resin content; g-i. (radial section) - uniseriate pitting on tracheids, 1-2 round pits in cross-fields, in vertical and also horizontal pairs. 

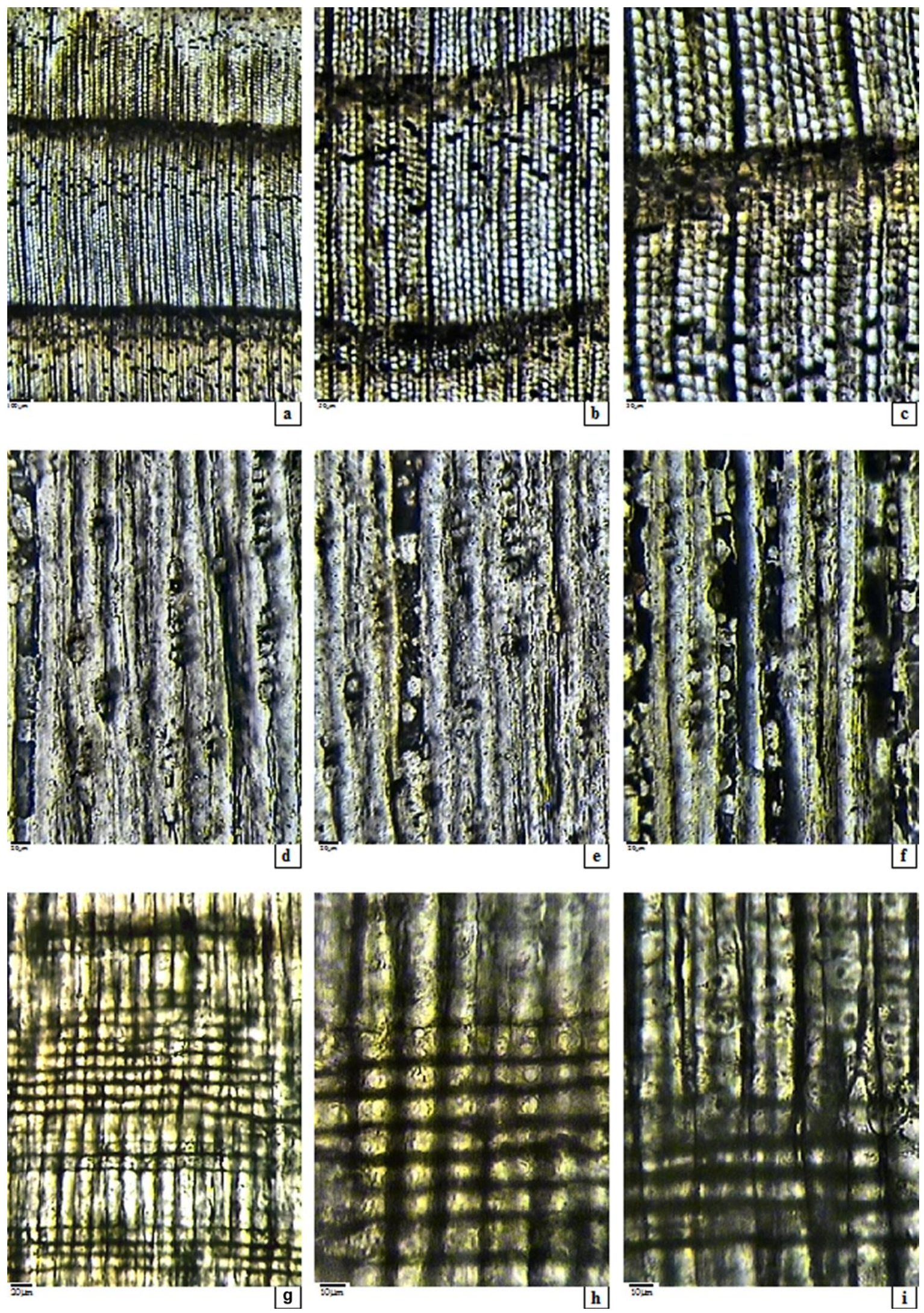

Fig. 2 a-i (graphic scale, $\mu \mathrm{m}$ ). Thujoxylon sp., Ociu, Bisericii brook, South Apuseni, Romania, sample OB-5.

a-c. Cross section - distinct growth rings, early-wood and late-wood tracheids, disperse parenchyma, uniseriate rays; d-f. (tangential section) - uniseriate short rays, parenchyma with nodular horizontal walls and resin content with round empty spaces and thick terminal walls; g-i. (radial section) - uniseriate pitting on tracheids, 1-2 round pits in cross-fields, vertical pairs also. 
taxodioid pits of 5-6 $\mu \mathrm{m}$ in diameter, horizontally arranged or in vertical pairs in the late-wood cross-fields, having rounded lens-like, inclined to vertical apertures. In the marginal cross fields 2-4, as superposed pairs of round pits are present.

\section{Affinities and discussions}

The palaeoxylotomical observations made on the studied specimens suggests, by the aspect of the structure in cross section, devoid of resin canals, with few parenchyma having horizontal nodular walls and cupressoid crossfields with typical aspect of a cupressaceous structure of Thujidae group, especially of Thuja type, even if some badly preserved details do not allow identifying a species. The identification key of Vaudois \& Privé (1971) explain that the cupressaceous structures have "zones d'acroissement distinctes, tracheides a ponctuations radiales abietineénnes uniseriées, parenchyme absent ou rare, a parois transversales noduleuses ou ponctuées, rayons généralement peu élevés, uniseriés, parfois biseriés sur un faible hauteur; champs de croisement contenant 1-4 ponctuations taxodioides, parfois cupressoides, indentures présentes" for Thuja type structure. The Chamaecyparis type has a lot of parenchyma and the Juniperus type has specific juniperoid nodules on the inclined tangential walls of ray cells in tangential view, details not observed in our specimens.

The fossil morphogenus, initially variably spelled as Thuyoxylum-Thuoxylon-Thuioxylon-Thuyoxylon, was correctly spelled as Thujoxylon by Hartig in 1848 (see Andrews, 1955, p. 251; Dijkstra \& van Ameron, 2002). Numerous morphospecies were described, in time (see also Vaudois \& Prive, 1971 revising the Cupressaceous fossil lignotaxa). Between the last described species, we cite Thujoxylon antissum Süss \& Velizelos, 1998, described from Lesvos, Greece, a tertiary form representing root-wood with a special pattern of growth rings and cross section. The species was quoted and discussed again by Mantzouka et al. (2013). Also, a Cretaceous species named Thujoxylon beipiaoense Ding et al., 2016, having similar features, was described from China.

Pretty badly preserved specimens were described from Romanian extra-Carpathian area as Cupressinoxylon sp. aff. Thujoxylon sp. (Iamandei et al. 2008, 2011, 2012).

Anyway, taking into account the papers of Greguss (1967), Dupéron-Laudouéneix (1979), Zalewska (1953), the revised diagnoses of Kräusel (1949) and Vogellehner (1967, 1968), and using the key of identification proposed by Vaudois et Privé (1971), we assign our studied specimens to Thujoxylon sp., and no more, due to bad preservation of the studied material.

Family Magnoliaceae Jussieu, 1789 nom. cons. (APG III 2009, APG IV 2016)

Genus Magnolioxylon Hofmann, 1952

Magnolioxylon kräuselii (Greguss) Van der Burgh, 1973

Fig. 3, Photos a-i.

\section{Material}

From a sample of petrified wood collected from South Apuseni mts., Ociu area, Bisericii Book, from MidMiocene deposits (Late Badenian-Early Sarmatian), kept within "Todea Collection", in Crișcior-Brad locality, under the indicative OB-1, with standard prepared thin sections that were submitted to the paleoxylotomical study.

\section{Microscopic description}

The growth rings are not too high, with boundaries marked by some tangential rows of thin-walled cells, radially flattened (marginal parenchyma). The structure is generally diffuse-porous or slightly semi-ring-porous, since in the late-wood the pores' size slightly diminishes. Also, at the boundary of the annual rings, the rays present typical slight dilations.

The vessels are arranged in 1-3 radial rows between two rays and are usually solitary or in radial small multiples of 2-4 vessels. The solitary pores seem to be oval in shape, usually deformed, relatively thick-walled (of 7-9 $\mu \mathrm{m}$ the double wall), sometimes touching the rays. The diameters of the solitary vessels are of 50-70 $\mu \mathrm{m}$. The vessel density is high, of more than 200 pores on $\mathrm{mm} 2$. The scalariform perforations plates have up to 10-12 quite thick bars. On the longitudinal walls, spiral thickenings are present, and intravascular pitting, as numerous pits, horizontal-elliptical, opposite, to almost scalariform, especially on narrower vessels appear. Sometimes, isolate tyloses inside the vessels are visible.

The axial parenchyma appears either as marginal bands at the ring boundary, or diffuse or scanty-paratracheal, or difficult to be observed due to bad preservation.

The rays, in cross-section seen, appear as 1-2 seriate, with slight dilations at the growth ring boundary, and consist of rectangular cells radially elongated, filled with some dark material. Generally, the rays have a linear or slightly curled trajectory and sometimes touch vessels. In tangential view it is obvious that the rays are 1-2-seriate, heterogeneous, and their frequency is of 6-10 rays on tangential horizontal $\mathrm{mm}$. They have 10-25 cells in height, or are even taller. In tangential-view the ray cells appear polygonal rounded and alternately arranged, sometimes slightly uneven. Radially seen, the rays show heterocellular character, the body cells are low, procumbent, and the marginals - slightly taller. In the cross-fields numerous short elongate superposed pits appear.

The fibro-tracheids have moderately-thick walls, and horizontal-elliptic pits, opposite to almost scalariform.

The fibres have also moderately thick walls but offer few details, due to bad preservation.

\section{Affinities and discussions}

Evaluating the observed xylotomical features in our studied specimen we found that some of them as scalariform perforations, scalariform pitting, biseriate rays, heterogeneous, terminal parenchyma and thick-walled fibers, which suggest similarity with members of Magnoliaceae, a large extant family comprising 7 genera and around 230 species, partially with arboreal habit, widespread in temperate to tropical areas from Eastern Asia and North America (see Watson \& Dalwitz, 1992). The Plant List 

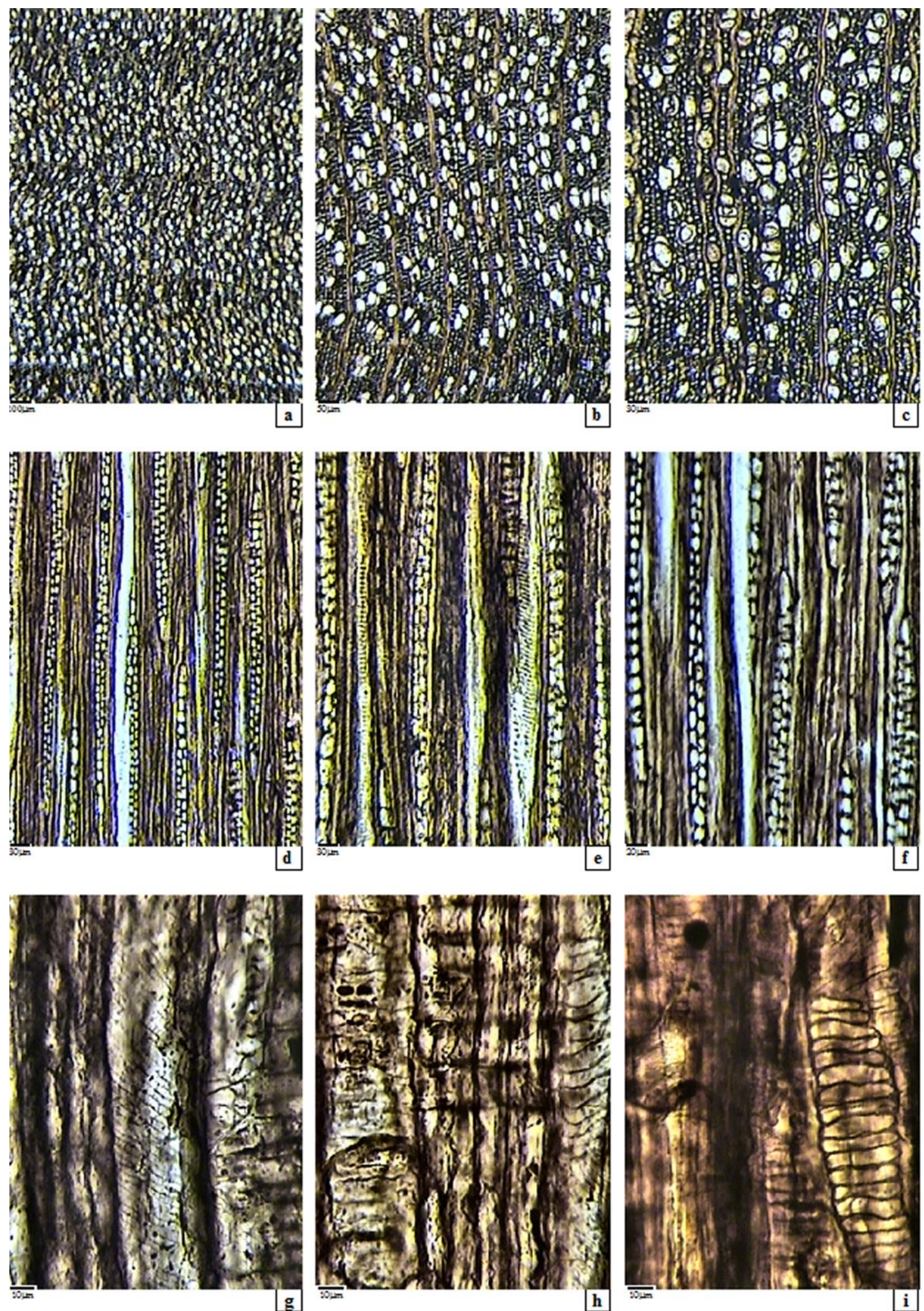

Fig. 3 a-i (graphic scale, $\mu \mathrm{m}$ ). Magnolioxylon kräuselii (Greguss) Van der Burgh, 1973, Ociu, Bisericii brook, South Apuseni, Romania, sample OB-1.

a-c. (cross section) - distinct boundary of growth ring, marked by marginal parenchyma and ray dilations; d-f. (tangential section) - spiral thickenings and scalariform pitting on vessels, biseriate heterogeneous rays; g-i. Radial section - spiral thickenings and scalariform pitting on vessels, scalariform perforation plates, pitted cross-fields. 
(2013) admits that Magnoliaceae is a family with 5 genera and 247 species.

However only three fossil genera were validly described till now, having different diagnoses:

- Liriodendroxylon Prakash, Březinová \& Bůžek, 1971, corresponding to the extant genus Liriodendron L., known as tulip tree, whose structure can be diagnosed as such: wood diffuse-porous, with small to mean-sized vessels, solitary or in multiples of two or more, having scalariform perforations plates with few bars (6-13), then angular to elliptic intervascullar pitting, opposite, in horizontal pairs or rows, terminal parenchyma, 1-5-seriate rays or broader, slightly heterogeneous, fibers with polygonal cross field, thin to thick walled and non-septate.

- Magnoliaceoxylon Wheeler, Scott \& Barghoorn, 1977, name used especially by American and Asian scientists, as morphogenus of fossil wood of Magnoliaceae, almost identical with the morphogenus Magnolioxylon created by Hofmann (1952), is characterized by numerous narrow vessels in cross-section, mostly in radial multiples, with exclusively scalariform perforation plates, with scalariform intervessel pitting, marginal (terminal) banded parenchyma and 1-4-seriate heterocellular rays (see Wheeler et al., 1977; Srivastava \& Suzuki, 2001; Wheeler \& Manchester, 2002).

- Magnolioxylon Hofmann, 1952, corresponding to the extant genera of magnolias such as Magnolia L., Michelia L., Talauma L., has the following diagnosis: diffuseporous wood with low growth rings, small solitary vessels or as multiples of 2-3 up to 5(7), and simple perforated plates, small to large vascular pitting. (Additionally, scalariform perforations and scalariform pitting, and even very specific ones appear - a reason to emend the genus' diagnosis). Rays 1-4(5)-seriate, rarely broader, with slightly sinuous trajectory in cross-section, with up to 22 cells in height, heterogeneous, body cells procumbent, marginals upright. Paratracheal uniseriate and marginal (terminal) parenchyma and thick-walled fibers are present.

The xylotomical details observed in our specimen, unfortunately rather badly preserved, support the assignment to Magnolioxylon morphogenus and, even if we had not the access some older identifications of magnoliaceous fossil woods (Unger, Caspary, Lignier, Edwards, and Kruse, for example) quoted by Schönfeld (1958), we compared our studied wood structure with more recently identified forms:

- Magnolioxylon michelioides Hofmann, 1952, the typespecies described from Prambachkirchen, Austria, has radial multiples of 3-5-7 vessels, paratracheal and terminal parenchyma, rays of two sizes - broad of 3-5 cells and uniseriates numerous which bring it closer to the extant species Michelia baviens L. It was, also, described from the Oligocene of Canada by Roy \& Stewart (1971), as having similar features or almost identical. Both forms are quite similar to our material.

- Magnolioxylon scandens Schönfeld, 1958, described from the German Late Oligocene of Niederrheinischen Bucht, shows diffuse-porous wood with thick growth rings, solitary vessels and in small radial multiples, sometimes diagonal to tangential, simple and high scalariform perforation plates (with up to 33 bars), scalariform intervascular pitting, thick-walled tracheids, round to scalari24 form pitted, thick-walled pitted libriform, 1-4-seriate high rays, heterocellular with 1-3(5) rows of marginal, thickwalled, upright cells (77-92 $(\mathrm{m}$ high). Schönfeld shows that these details suggest similarities with extant species like Magnolia and Talauma, but also with some lianas like Schisandra, Kadsura. The same species was described by us from Mid-Miocene deposits of Prăvăleni, South Apuseni area (Iamandei et al., 2004), but is not identical to here studied specimen.

- Magnolioxylon transilvanicum Nagy \& Mârza, 1967, was described also from South Apuseni area. The wood structure presents bi- and triseriate heterocellular rays, with body ray cells procumbent, and with mostly 2-4 rows of upright and/or square marginal cells, platanoid dilations at the boundary of the growth-rings, simple and scalariform perforations, elongated to scalariform pits on vessels, simple and bordered, with slit-like apertures, scanty paratracheal axial parenchyma and, also, marginal (terminal), tracheids with spiral thickenings and scalariform pits, septate and pitted fibres. The same species was subsequently identified in the same area (Iamandei \& Iamandei, 1997), having 2-3-seriate rays, idioblastic secretory cells, scalariform perforations, bordered elliptic to scalariform pitting, quite similar, of "buttonhole" type on fibro-tracheids and on fibers. Also, a Miocene Magnolioxylon cf. transilvanicum was described from Bala area, Mehedinţi County, Romania (Iamandei et al., 2011) and recently Magnolioxylon aff. transilvanicum in Rhodopes mts. (Iamandei et al., 2016).

- Magnolioxylon acuminatum Iamandei et Iamandei, 1997, is another species described from Prăvăleni, close to Ociu area, from the same Mid-Miocene deposits. It is characterized by distinct growth rings, semi-ring-porous structure wits radial multiples of 2-3(7) mean-sized vessels (84/66 (m), density 105-120 vessels on sq.mm., simple perforations, alternate to opposite vascular pits, vasicentric tracheids with spiral thickenings and thin-walled tyloses, apotracheal parenchyma, diffuse and marginal, heterocellular rays usually uniseriate, with 1-4 secretory cells, 1-2 pits in cross-fields thick-walled pitted fibers (Iamandei \& Iamandei, 1997).

- Magnolioxylon sp., described by Petrescu \& Nuţu (1970) also from Prăvăleni, from the same formation, has badly preserved anatomical details - solitary vessels or in 2-3 radial multiples and 1-4-seriate rays, typical generic details - but not sufficient for a specific identification.

- Magnolioxylon parenchymatosum Van der Burgh, 1973, described from the Late Oligocene of Niederrheinischen Braunkohlenformation, presents many xylotomical similarities with the extant species Magnolia fraseri and M. sororum and, also, with the fossil species Magnolioxylon scandens described by Schönfeld (1958) from the same deposits, having small sized vessels, with scalariform perforation plates with 2-12 spaced bars, intervascular scalariform pitting, helical thickenings, and also pitted tracheids and fibers, axial parenchyma diffuse and 1-3banded and marginal (terminal), 1-3-seriate heterocellular rays, with body-cells procumbent, and two rows of marginal upright cells, pitted.

- Magnolioxylon kräuselii (Greguss) van der Burgh 1973, initially described by Greguss (1969) as Liquidambaroxylon, presents, besides the generic details, simple and sca- 
lariform perforations with (3)10-12 spaced thick bars, sometimes forked, pitted and crystalliferous parenchyma, 1-2-seriate rays of 10-16 cells high, heterocellular, thick to very thick-walled fibers, pitted fibro-tracheids.

Since the here studied specimen has scalariform perforations with up to 10-12 spaced thick bars, sometimes forked, pitted and crystalliferous parenchyma, 1-2-seriate heterocellular rays, of 16-17 cells high, or more, thick to very thick fibers, pitted fibro-tracheids, perfectly resembles to the morphospecies Magnolioxylon kräuselii (Greguss) Van der Burgh, 1973, to which we attribute our studied specimen.

Family Platanaceae Lestiboudois, 1826 (ex Dumortier, 1829), nom. cons. (APG III 2009, APG IV 2016)

Genus Spiroplatanoxylon Süss 2007

Spiroplatanoxylon densiradiatum (Petrescu) Süss 2007

Fig. 4, a-i; Fig. 5, a-i.

\section{Material}

From two samples of petrified wood collected from South Apuseni mts., Ociu area, Bisericii Book, from MidMiocene deposits (Late Badenian-Early Sarmatian), kept within "Todea Collection", in Crișcior-Brad locality, under the indicative OB-2 and OB-6, with standard oriented thin sections that were submitted to the paleoxylotomical study.

\section{Microscopical description}

The growth rings are distinct, the wood structure is diffuse-porous to slightly semi-ring-porous and the rays are dilated at ring boundaries.

The vessels appear, in cross-section, as solitary pores or as tangential to diagonal pairs, sometimes slightly angular, rounded or deformed and moderately thick-walled, 7$10 \mu \mathrm{m}$ the double wall. The woody bundles, between two rays, may have 1-5 vessels, which are mean sized, with the radial/tangential diameters ratio 30-63/15-35 $\mu \mathrm{m}$ The pores' size is relatively uniform $275-360$ per square mm, we can talk about a diffuse-porous wood tending to semiring-porous, since a gradually diminishing size is observed to the late-wood, where smaller sized pores are visible, of $15-30 / 12-15 \mu \mathrm{m}$ the diameters ratio (r/tg). In longitudinal sections scalariform perforations can be seen, on tilted plates, with $12-18$ or more thin bars, quite badly preserved. The vessels' walls are bordered pitted, with opposite, horizontaly elongate pits to scalariform, by apertures' coalescence. Even if badly preserved, helical thickenings are present, no tyloses inside the vessels appear, and the vessels' elements length is of $80-200 \mu \mathrm{m}$, or difficult to measure.

The axial parenchyma is of apotracheal type, diffuse, as scattered cells among the fibers or as uniseriate short lines and as marginal (terminal) parenchyma. In longitudinal view, the parenchyma cells are thin-walled, probably simple pitted, and have strands of rectangular chambered cells, empty or bearing prismatic crystals.

The rays, in cross section seen, have linear trajectory, rectangular cells, are two-sized, of 1-4, respectively, (6)812 cells wide, and have typical platanoid dilations at ring boundaries. In tangential view they appear fusiform and compact, sometimes have cell-sheath and are usually high. The body ray-cells are slightly polygonal, unequally sized and relatively thick-walled. The uniseriate ray endings have 1-5 slightly polygonal cells, often slightly larger. The ray-frequency is of 9-12 rays per tangential $\mathrm{mm}$. Radially seen, the rays appear heterocellular, with procumbent body cells, the marginals square or slightly taller. Sometimes hypertrophied cells appear, most probably secretory and/or bearing crystals.

The fibres, polygonal in cross section, have rounded lumina, and are quite thick-walled (up to 3-5 $\mu \mathrm{m}$ double wall). The longitudinal walls are pitted, but quite badly preserved.

\section{Affinities and discussions}

All the observed microscopical features in the studied specimens showed in cross-section a diffuse-porous to semi-ring-porous vessels' distribution, opposite bordered pits, horizontaly elongate to scalariform by apertures' coalescence on vessels, spiral thickenings and scalariform perforations, and heterocellular rays dilated at ring boundary (typical "platanoid dilatations"), so, we appreciated that there are clear similarity with the platanaceous structure. The Platanaceae is a monogeneric family of flowering plants, from the order Proteales. Platanus is a large deciduous tree adapted to temperate climate and has 10-12 species and some hybrids, scattered in North America, Southeast Europe, Southern and Eastern Asia. Its secondary xylem has moderately small vessels in radial small groups, having scalariform and simple perforations, intervascular bordered pits elongate to scalariform parenchyma apotracheal, two-sized rays with typical platanoid dilation at the ring boundary (Greguss, 1959; Watson \& Dallwitz, 1992)

As it is known, there are three still valid fossil genera of platanaceous woods: Plataninium, Platanoxylon and Spiroplatanoxylon. Extended discussions concerning the validity of these genera and of their associated species are already published (Süss, 2007; Sakala et al., 2010; Gryc \& Sakala, 2010; Továrková et al., 2011; Koutecky \& Sakala, 2015; Iamandei et al., 2020, in this Journal).

- The genus name Plataninium is still used by some American, Asiatic and even European scientists, and is considered as a primitive type which support the Bayley concept regarding the xylotomic features' evolution (see Wheeler \& Baas, 1991) since it has scalariform perforations, spiral thickenings, marked heterocellular rays. Many scientists have described species under this genus name (see Felix, 1894; Brett, 1972; Crawley, 1989; Poole et al., 2002; Meijer, 2000; Page, 1968; Stockmans, 1936; Wheeler, McClammer \& LaPasha, 1995; Takahashi \& Suzuki, 2003).

- The genus Platanoxylon Andreánszky, 1951 was also subject of revision and dispute at least in the last time (Süss 1960, 1971, 1986, 2007; Süss \& Müller-Stoll, 1977). This genus is considered by Selmeier (1996) as representing an evolved type which has simple (and scalariform) perforations, no spiral thickenings and homocellular rays, and was longtime admitted as the best equivalent of the extant platanoid taxa (Süss, 1960, 1971, 1980, 1986, 2007; Süss \& Müller-Stoll, 1977). 

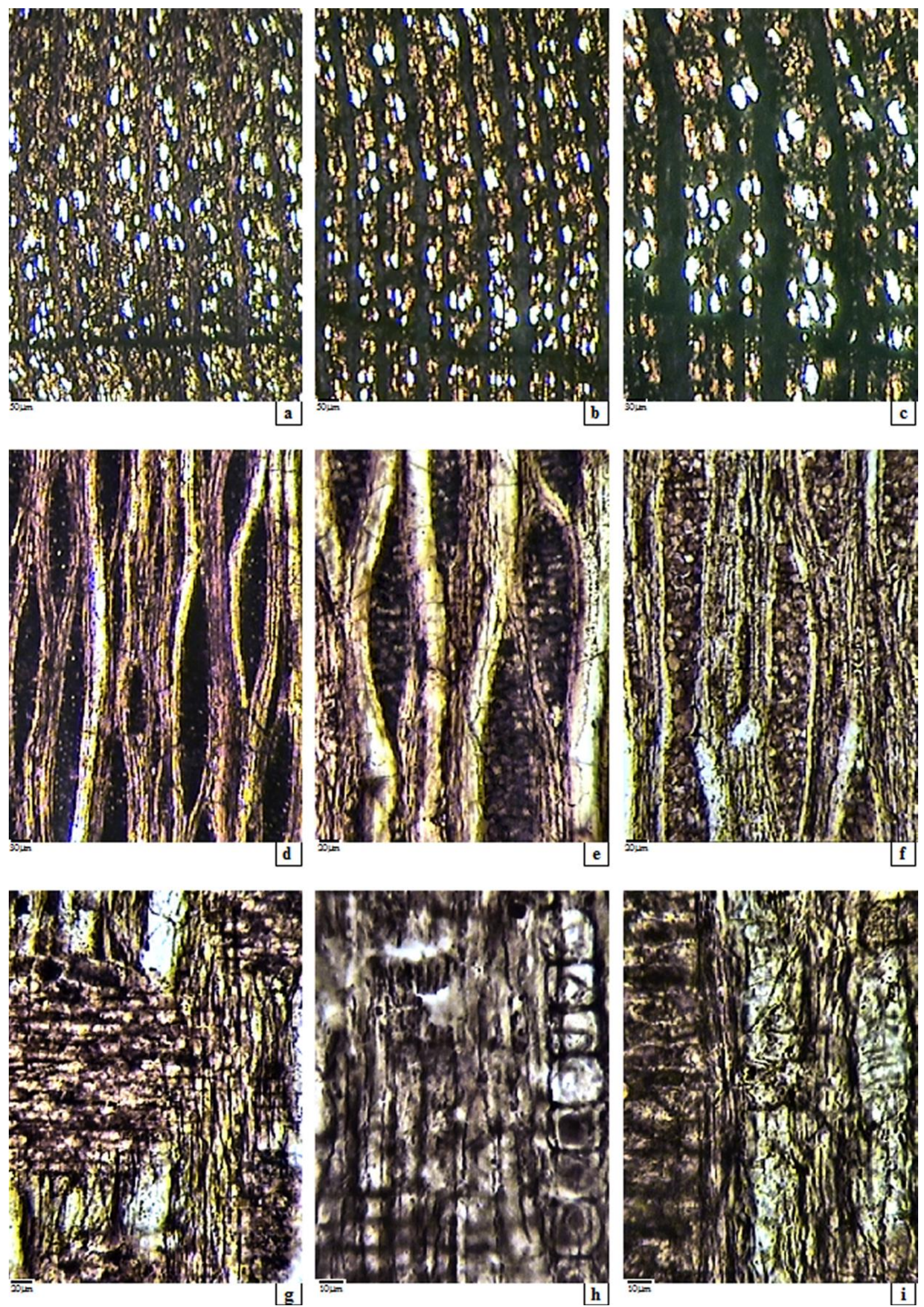

Fig. 4 a-i (graphic scale, $\mu \mathrm{m}$ ). Spiroplatanoxylon densiradiatum (Petrescu) Süss 2007, Ociu, Bisericii brook, South Apuseni, Romania, sample OB-2.

a-c. (cross section) - distinct boundary of growth ring, diffuse-porous wood structure, ray dilatations at boundaries; $\mathbf{d - f}$. (tangential section) - two-sized rays - fine and multiseriate fusiform, spiral thickenings on vessels; g-i. (radial section) procumbent body ray cells, chambered crystalliferous parenchyma, scalariform perforation plates. 

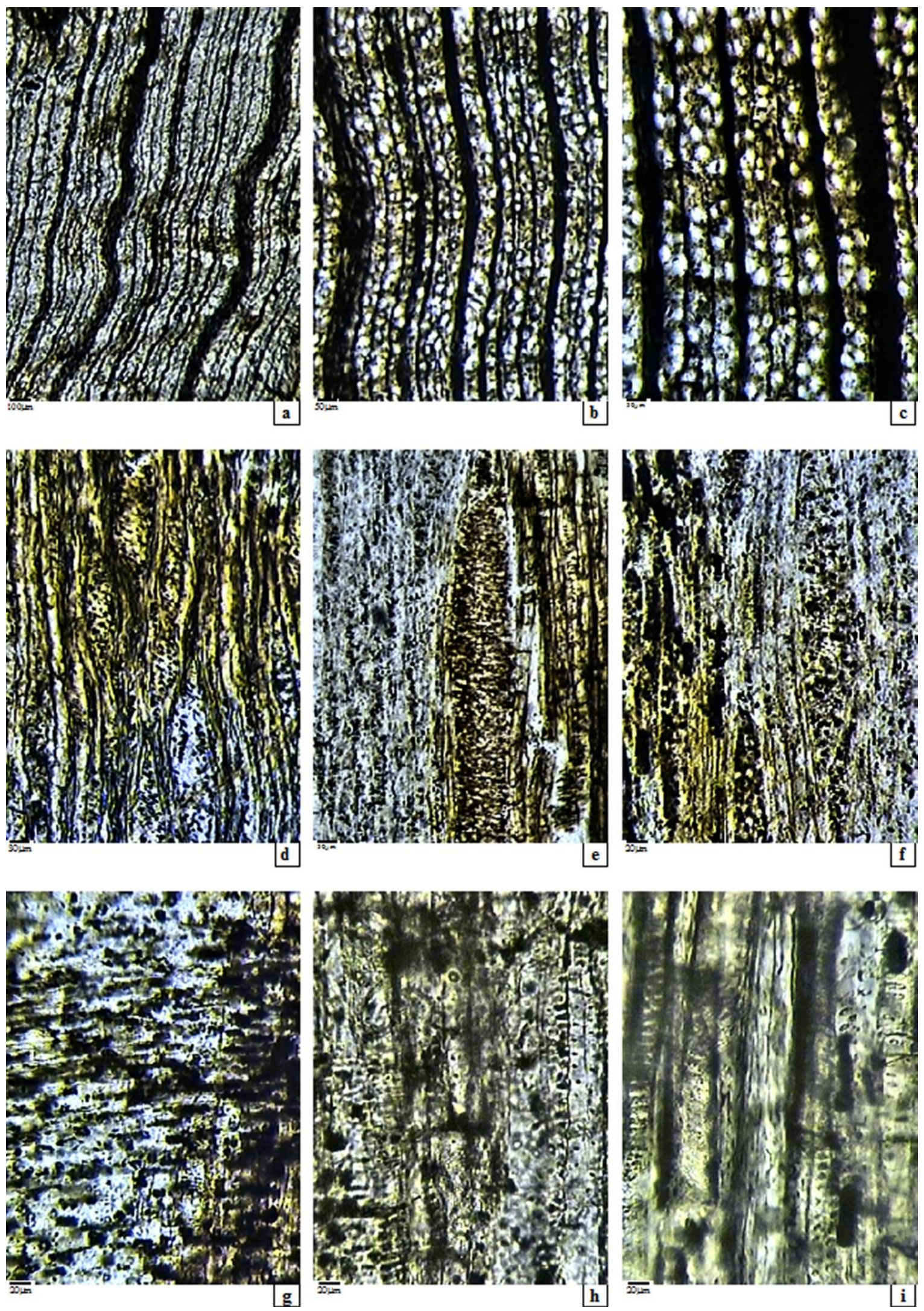

Fig. 5 a-i (graphic scale, $\mu \mathrm{m}$ ). Spiroplatanoxylon densiradiatum (Petrescu) Süss 2007, Ociu, Bisericii brook, South Apuseni, Romania, sample OB-6.

a-c. (cross section) - distinct boundary of growth ring, diffuse-porous wood structure, two-sized rays with dilations at boundaries; d-f. (tangential section) - two-sized rays - fine and multiseriate; g-i. (radial section) - heterocellular ray, scalariform pitting on vessels, chambered crystalliferous parenchyma. 
- The genus name Spiroplatanoxylon Süss, 2007 was created from the Tertiary of Europe and southwestern Asia and is characterized, beside the Platanus-like wood structure, by two aspects considered more primitive but characteristic to the genus: the scalariform perforation plates and the helical thickenings on vessels. From this reason a lot of species of Plataninium and Platanoxylon were attributed to Spiroplatanoxylon (see Süss, 2007; Gryc \& Sakala, 2010). Also, Icacinoxylon was reconsidered as bad identification of a taxon with only intertropical extant correspondents and the numerous species described in Europe, but not only, were reassigned to Spiroplatanoxylon (Süss, 2007).

In a recent paper on some wood remains from Bozovici, an extended discussion on the evolution of the taxonomy of the fossil platanaceous structures is done (Iamandei et al., 2020, in this Journal). All the described xylotomical features of the studied specimens are consistent with the genus diagnosis of Spiroplatanoxylon, and for this reason we will attribute our woods to it.

Since the wood structure of here studied specimens from South Apuseni mts., from Ociu locality, on Church Brook, xylotomically resembles to many already described species, for example to the forms described, by Petrescu \& Dragastan (1972) as Spiroplatanoxylon grambastfessardi (Petrescu) Iamandei (in Iamandei et al., 2020, in this Journal), from the Oligocene of Telega and, also, by Petrescu \& Nuţu $(1970,1971,1972)$ from Prăvăleni, respectively from Almaşul Mare and Boiu, as to Spiroplatanoxylon porosum (Felix) Süss, 2007 and also with the species Spiroplatanoxylon densiradiatum (Petrescu) Süss, 2007 (former Icacinoxylon densiradiatum Petrescu, 1978) which is almost identical, having smaller angular vessels, solitary or in clusters, scalariform perforation plates with 20-35 bars, spiral thickenings and ray cells with crystals, two-sized rays and high rayfrequency.

We tried to find very specific details, to discriminate between the described species, and to identify the studied material, which is quite badly preserved, but showing distinct growth rings, diffuse-porous wood structure to slightly half-ring-porous, vessels solitary or in tangential to diagonal pairs, angular to rounded, thick-walled, meansized, scalariform perforations with 12-18 thin bars or more, bordered opposite pits, horizontally elongate to scalariform by apertures' coalescence, helical thickenings, no tyloses; axial parenchyma apotracheal diffuse, and as marginal parenchyma, thin-walled cells in strands of rectangular chambered cells, bearing prismatic crystals; rays, two-sized (1-4 and (6)8-12 cells wide), with platanoid dilations, fusiform and compact usually high, sometimes cell-sheath, body ray-cells slightly polygonal, unequally sized, thick-walled, rays heterocellular, with procumbent body cells and marginals square or slightly taller, sometimes with hypertrophied cells probably secretory and/or bearing crystals, fibres polygonal, thickwalled, pitted. Since we appreciate a close similarity with Spiroplatanoxylon densiradiatum (Petrescu) Süss, 2007, we assign our two studied specimens to this species.

Family Fagaceae Dumortier, 1829 nom. cons. (APG III2009, APG IV-2016)
Genus Quercoxylon (Kräusel) Müller Stoll \& Mädel, 1957 emend. Gros, 1988

Quercoxylon sp. cf. Quercus frainetto Tenore

Fig. 6, a-i.

\section{Material}

From a sample of petrified wood collected from South Apuseni mts, Ociu area, Bisericii Book, from MidMiocene deposits (Late Badenian-Early Sarmatian), kept within "Todea Collection", in Crișcior-Brad locality, under the indicative OB-3, with standard prepared thin sections that were submitted to the paleoxylotomical study.

\section{Microscopic description}

The growth rings in cross-section are distinct, but with not well marked boundaries by a special tissue; the wood structure is ring-porous and shows an abrupt change between the early and the late-wood: from few solitary, round, big, early-wood vessels, to smaller, solitary, round or slightly oval late-wood vessels, in radial pattern arranged, to slightly diagonal or as composed fascicles arranged, from dendritic to almost porous arrangement, the pores' size gradually diminishing to the final wood.

The vessels in the early wood, are exclusively solitary, round, large sized of 200-350 $\mu \mathrm{m}$ in diameter and thickwalled (of 5-7 $\mu \mathrm{m}$ the simple wall), in 1-3 tangential rows arranged. In the transitional to late wood, round to radial oval, small sized vessels appear (of 90-150/70-130 $\mu \mathrm{m}$ $\mathrm{r} / \mathrm{tg}$ diameters), also exclusively solitary and thick-walled. The vessels' density is variable, of 2-3 pores per square millimeter in the early-wood, more numerous (11-14) only in the late-wood (mean density is between 7-11 pores, variably-sized, per square millimeter). In longitudinally view, the vessels have simple perforation plates, quite difficult to see due to bad preservation. On vessels and on vasicentric tracheids, alternate bordered pits with horizontal apertures appear.

The axial parenchyma is less visible in cross section, must be diffuse, of apotracheal type, scattered among the libriform or tracheids. In longitudinal sections can be seen as vertical strands of rectangular chambered cells among the elements of ground-mass, or even paratracheal. Due to bad preservation no other detail is visible.

The rays, in cross-section seen, appear linear, slightly wavy in the early wood and are two-sized: fine rays, mostly uniseriates, short and numerous and broad rays, compact multiseriates of 8-15 cells, often taller than 1 $\mathrm{mm}$. Tangentially they show polygonal cells, unequal in size - of $12-25 \mu \mathrm{m}$ in diameter, and relatively thin-walled (2-3 $\mu \mathrm{m}$ the double-wall). The ray-frequency is variable, of 10-14 rays on tangential millimeter, the multiseriates being rare and, at relatively uniform intervals. Radially, the rays are homocellular showing cells all procumbent, and the cross fields have vertical-rectangular bordered pits, in palisade arrangement.

The fibers, transversally seen, appear as thick-walled cells with point-like lumina. In longitudinal view, they are unpitted and unsepted. The fibro-tracheids are relatively similar to the fibers and difficult to separate in all sections, due to bad preservation. 

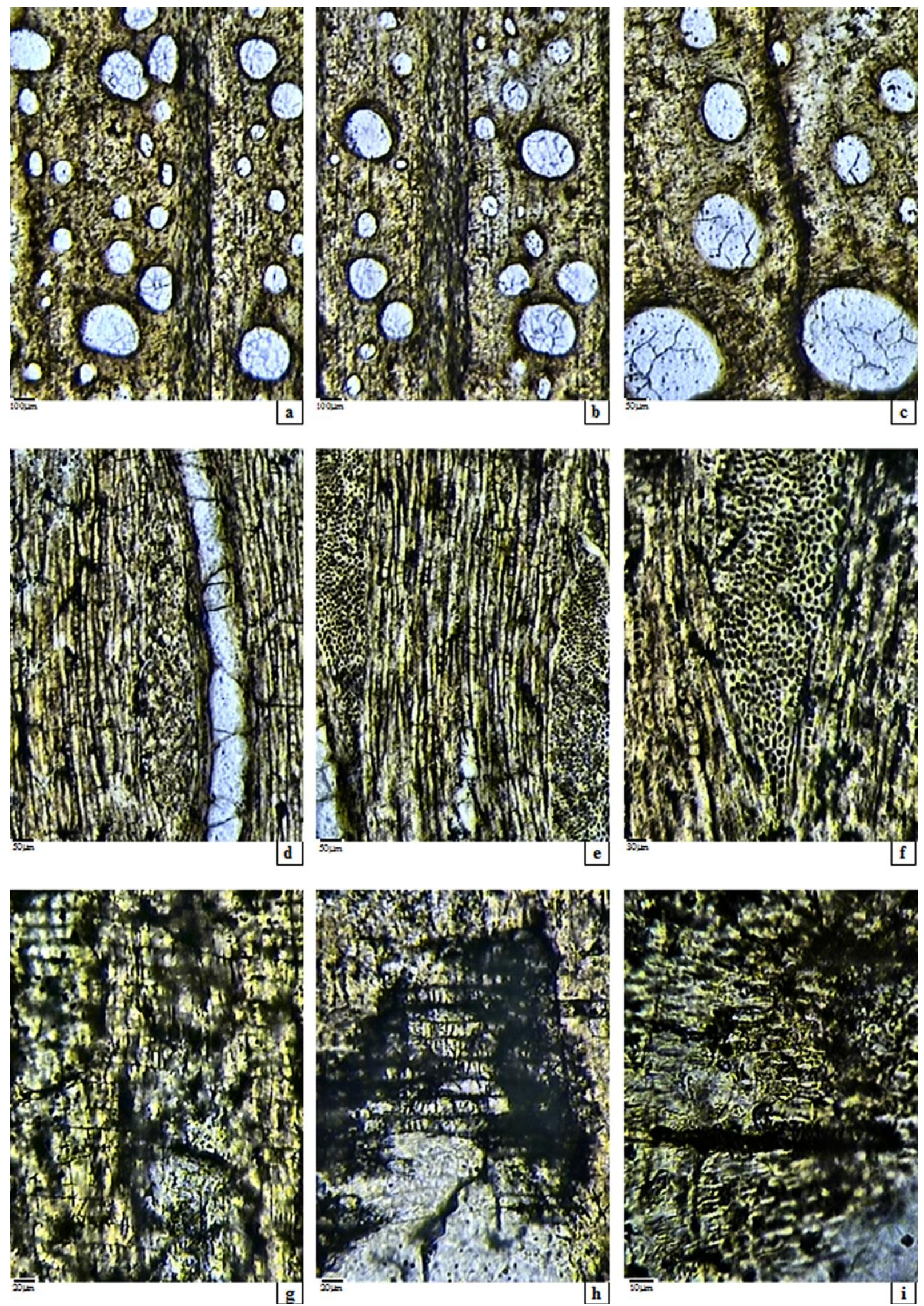

Fig. 6 a-i (graphic scale, um). Quercoxylon sp. cf. Quercus frainetto Ten., Ociu, Bisericii brook, South Apuseni, Romania, sample OB-3.

a-c. (cross section) - indistinct boundary of growth ring, ring-porous wood structure, two-sized solitary thick-walled vessels, round late-wood vessels two-sized rays. d-f. (tangential section) - two-sized rays, fine and multiseriate, short vascular elements, parenchyma cells. g-i. (radial section) - bordered pits with horizontal apertures on vessels, simple perforation plates, rectangular pits "in palisade" in cross fields 


\section{Affinities and discussions}

The cross-section of the studied specimen shows a typical aspect of wood of Fagaceae, i.e. obvious ring-porousity, rounded pores and two-sized rays, finer, mostly uniseriate and multiseriates broad, typical features of some quercineous structures. After Hadziev \& Mädel (1962) for the extant oaks could be separated four types of wood structures:

- Type white oaks (Weisseichen), comprising most of the species of Lepidobalanus sectio - having ring porous structure and small, polygonal, thin-walled vessels in the late wood.

- Type red oaks (Roteichen), comprising the species of Eritrobalanus sectio and some species of Lepidobalanoideae section, with ring-porous structure and relatively large, round, thick-walled vessels in the late wood.

- Type sempervirent oaks, comprising species of Quercus and of Lithocarpus with (diffuse)-porous or semi-ringporous structure, and relatively small and spaced vessels often radially arranged in the late wood.

- Type oak root-wood, present in all the Quercineae, having diffuse-porous structure and crowded large pores.

Privé-Gill (1975), observed that the oak-wood is characterized by vessels in radial rows, more or less dendritically distributed, and simple perforated, specifying that twosized rays (fine, 1-2-seriates and broad, multiseriates) are present in Quercus L. and in Lithocarpus Bl. (= Pasania Oerst.) with some tens of species from temperate to warm regions of north hemisphere, islander also. The structures with diffuse pore distribution characterize the evergreen species. The ring-porous structure is typical to the deciduous species of Quercus and the most septentrional species of Lithocarpus. In the root-wood, the deciduous species often tend to lose their ring-porousness becoming similar to the evergreen species, and the broad rays become divided in false rays, i.e. aggregate rays (Privé-Gill, 1975).

Also, for a correct generic identification, other two keys of identification were consulted:

- The key of Shimanji (in Suzuki \& Ohba, 1991) who made a comparative synthesis of the essential xylotomical characters of the extant fagaceous taxa, based on the anatomic studies and the phylogenetic relations between the genera of Fagaceae, comprised in a big table presented. Using this key we observed that having ring porous structure, round thick-walled vessels in latewood, simple perforations and compact thick rays, our structure can be similar to a Quercus of white type from Quercus section. - The key of Petrescu (1976), systematizing the extant and fossil Fagaceous wood-types (Table 1), and separating them by ring structure, perforated plates and ray-type, key slightly emended here by us, since Lithocarpoxylon is considered invalid genus (Selmeier, 1997). Using at least these keys, the generic identification as Quercoxylon of our specimen is correct. Consulting, also, the atlas of Schweingruber (1990), the onward site of Schoch et al. (2004), the site InsideWood 2004-onwards, and the paper of Wheeler (2011), we also found a perfect similarity of our studied specimen with the quercineous structure.

This fossil genus Quercoxylon was initially created by Elise Hofmann (1929), when she quotes the species Quercoxylon cerris, but without Fig.s or description, so, 30 it was considered not correctly published. Ten years after, it was Kräusel (1939) who correctly defined and imposed the genus name Quercoxylon, describing a new species, Q. retzianum Kräusel, 1939, and establishing it as typespecies, giving a correct genus' diagnosis, as it follows: Secondary wood porous or ring porous, with more or less obvious growth rings, usually solitary vessels with simple perforations, with big alternate pits, bigger to parenchyma or to ray cells, from irregular oval to polygonal, usually vertical; specific two-sized vessels and tracheids; libriform fibres and parenchyma difusse, or as short tangential uniseriate bands; two-sized rays, short uniseriate, sometimes as false broad rays, and real broad rays, compound, compact and aggregate.

This genus diagnosis was emended by Müller-Stoll \& Mädel (1957), and again by Gros (1983, 1988), to comprise new specifications on the porous or ring-porous structure, on the usually solitary vessels simple perforated and with alternate vascular pitting, on the pitted parenchyma, banded or diffuse, on the libriform, tracheids and small vessels from groundmass and on the two-sized rays.

Another revision and emendation was made by Suzuki \& Ohba (1990), they proposing to get out from the confusion with many other older validly published generic names of oak wood-structures as Kloedenia, Quercinium, Quercites, Quercoxylon, by sending them in synonymy, and replacing them with the Linnaean name Quercus, but this proposal not respecting the current ICBN rules was not followed by any paleoxylologist (see Selmeier, 1997). They also emmended the genus Lithocarpoxylon Petrescu, 1978 which was invalidated by Selmeier (1997).

Reviewing many extant described species of "white oak", Privé-Gill (1975) conclude that there is a big intraspecific variation. This is true for the entire genus Quercus L., which shows a great interspecific anatomic homogeneity and in such a situation, it is very difficult to delimitate a fossil species and, often, any xylotomic observation has only a descriptive value for the studied specimen (PrivéGill, 1975).

Selmeier (1996) observed also that vessel diameter, ray size, ray frequency and ray distribution are variable, and even in the same described fossil species the biometric values may differ. For this reason, in the xylotomical description of extant wood we find no actualized measurements, and any accurate measurements made by paleoxylologists cannot be always useful to identify an unknown. Much more, the rules from "IAWA List of Microscopic Features for Hardwood" (Wheeler at al., 1989) impose different ways to express the older measurements. A lot of other oak fossil woods described from the European Miocene were usually identified with "white oaktype", as Quercoxylon bavaricum Selmeier, 1971, a perfect equivalent of the extant Quercus robur L. which belong to Quercus section.

This species described by Selmeier (1971) have a correspondent within Carpathian area in Quercoxylon sarmaticum Starostin \& Trelea, 1969 which seems to have priority, defining the same type of wood which was found again by Petrescu (1976), Lupu (1984), Iamandei et al. (2001, 2011).

The xylotomical analysis of here studied specimen shows that it should belong to "Roteichen" type, from 
Table 1 Key of identification of Fagaceous wood (after Petrescu, 1976, slightly modified)

\begin{tabular}{|l|l|l|l|l|}
\hline & Vessels, perforations & Rays & Extant taxa & Valid fossil taxa \\
\hline \multirow{3}{*}{ Type A } & $\begin{array}{l}\text { Structures with solitary ves- } \\
\text { sels or grouped (2-3 or more), } \\
\text { with simple and scalariform } \\
\text { perforations on vessels }\end{array}$ & $\begin{array}{l}\text { Fine rays (1-3-seriate) and } \\
\text { compact multiseriate. }\end{array}$ & $\begin{array}{l}\text { Fagus } \\
\text { Nothofagus }\end{array}$ & $\begin{array}{l}\text { Fagoxylon, Notho- } \\
\text { fagoxylon }\end{array}$ \\
\hline \multirow{2}{*}{ Type B } & $\begin{array}{l}\text { Structures with solitary ves- } \\
\text { sels, simple perforated, some- } \\
\text { times some scalariform, with } \\
\text { few bars }\end{array}$ & $\begin{array}{l}\text { Uniseriate and compact mul- } \\
\text { tiseriate rays, sometimes } \\
\text { compact-composed or, par- } \\
\text { tially aggregate rays }\end{array}$ & Quercus \\
\cline { 2 - 4 } & $\begin{array}{l}\text { Cniseriate and multiseriate } \\
\text { aggregate rays }\end{array}$ & Lithocarpus & Quercoxylon \\
\hline
\end{tabular}

Erytrobalanus sectio, since they present in cross section, ring porous structure and small, round, thick-walled vessels in late wood, with radial or tending to dendritic pattern distribution of the vessels, or to already porous even if they may have many variations, as some other authors previously have been shown (see Selmeier, 1971; Privé, 1975).

At a first sight, the here studied wood structure seems to correspond to the extant Quercus borealis L. (in Schweingruber, 1990), known now as synonym of extant Quercus rubra L., which belong to the red oak group (Quercus, section Lobatae), living now in North Ameri$\mathrm{ca}$, in the northeastern United States and southeast of Canada, locally named "Northern Red Oak" or "Champion Oak". Also, similarities of the structure of our specimen with the extant Quercus suber (cork oak) and with the fossil Quercoxylon compactum (Starostin \& Trelea, 1969) were observed.

However, the cross-fields with vessels show in a homocellular ray structure numerous quadrangular rounded vertically aranged bordered pits, in palissade, very similar to extant species Quercus frainetto Ten. (see Schweingruber, 1990), known as Hungarian Oak or Italian Oak (synonyms: Quercus conferta Kit., Quercus farnetto Ten.) classified in Quercus sect. Mesobalanus, and is a species of oak native to Southeastern Europe and Turkey.

A similar specimen was described by us, from the Middle Miocene from Bala area, Mehedinţi County, Romania (Iamandei et al., 2011). In these circumstances we prefer to give to the here studied specimen the name Quercoxylon sp. cf. Quercus frainetto Ten., and to search for a better fossilized specimen, or specimens, which could support the description maybe of a new species.

\section{CONCLUSIONS}

Previous evaluation of the ecological requirements of the paleotropical taxa in Prăvăleni-Ociu association concluded that the arboreal Badenian vegetation represents an altitudinally storied Mixed Mesophytic Forest with Lauracee and Conifers, living in an insular mountainous environment within an equal climate, warm and wet, devoid of freezing intervals. Otherwise the regional palaeogeographic reconstruction indicates lower latitude of the area and a Mediterranean environment inside Paratethys. After our fossil wood identifications the list of arboreal flora comprises species of Tetraclinoxylon, Thujoxylon, Chamaecyparixylon, Taxodioxylon, Sequoioxylon, Pinuxylon, Magnolioxylon, Cinnamomoxylon, Spiroplatanoxylon, Liquidambaroxylon, Eucaryoxylon, Rhysocaryoxylon, Pterocaryoxylon, Fagoxylon, Quercoxylon, Alnoxylon, Populoxylon, Salicoxylon, Nyssoxylon, Paraphyllanthoxylon, Piranheoxylon, Aceroxylon, Fraxinoxylon, Rhizopalmoxylon (see Iamandei et Iamandei, 2010), to which we are adding newly identified species of Thujoxylon type, of Magnolioxylon, of Spiroplatanoxylon and of Quercoxylon, perfectly integrated within the late Badenian regional vegetation.

\section{ACKNOWLEDGEMENTS}

The palaeoxylotomical study for this paper was supported by the Geological Institute of Romania, which offered the best conditions of research, and to which we thank! Also, we thank to reviewers, Dr. Akkemik, Ü. and to Dr. Paraschiv V., who made valuable observations on the scientific content, helping us to improve this paper.

\section{REFERENCES}

Andreánszky, G., 1952. Der versteinerte Wald von Mikofálva und einge andere verkieselte Baumstämme aus Ungarn. Annales Biologicae Universitatum Hungariae, 1: 15-24.

Andrews, H.N., 1955. Index of Generic Names of Fossil Plants, 1820-1950: Based on the Compendium Index of USGS. Geological Survey Bulletin, 1013: 0-101. https://books.google.ro/books?id=s6oPAAAAIAAJ\& $\mathrm{pg}=\mathrm{PA} 251 \& \mathrm{lpg}=$ Thujoxylon $\& \mathrm{f}=$ false

APG III - 2009. An update of the Angiosperm Phylogeny Group classification for the orders and families of flowering plants: APG III. The Angiosperm Phylogeny Group*1. Botanical Journal of the Linnean Society, 2009, 161: 105-121. With 1 Fig. https://doi.org/10.1111/j.1095-8339.2009.00996.x

APG IV - 2016. An update of the Angiosperm Phylogeny Group classification for the orders and families of flowering plants: APG IV (The Angiosperm Phylogeny Group: Chase M.W., Christenhusz, M.J.M., Fay, M.F., Byng, J.W., Judd, W.S., Soltis, D.E., Mabber- 
ley, D.J., Sennikov, A.N., Soltis, P.S. \& Stevens, P.F.). Botanical Journal of the Linnean Society, 181(1): 1-20; https://doi.org/10.1111/boj.12385

Brett, D.W., 1972. Fossil wood of Platanus from the British Eocene. Palaeontology, 15: 496-500.

Crawley, M., 1972. Dicotyledonous wood from the Lower Tertiary of Britain. Palaeontology, 32(3): 597-622.

Dijkstra, S.J. \& Van, Ameron, H.W.J., 2002. Fossilium Catalogus. Plantae. Pars 104. Gymnospermae (5) (Ginkgophyta et Coniferae). 1. Supplement Sequoia Ulangangia. (Van Ameron, H.W.J. editor) Publisher: Backhuys, 104.

Ding, Q., Tian, N., Wang, Y., Jiang, Z., Chen, S., Wang, D., Zhang, W., Zheng, S., Xie, A., Zhang, G. \& Liu, Z., 2016. Fossil coniferous wood from the Early Cretaceous Jehol Biota in western Liaoning, NE China: New material and palaeoclimate implications. Cretaceous Research, 61: 57-70. http://www.sciencedirect.com/science/article/pii/S019 5667115301361 - aff1

Dumortier, B.C.J., 1829. Analyse des Familles des Plantes, avec l'indication des principaux genres qui s'y rattachent. Publisher J. Casterman, Tournai, 104 pp.

Dupéron-Laudouéneix, M., 1979. Étude d'un bois homoxylé du Tertiaire de Charente. 104e Congrés national des sociétés savantes, Bordeaux, 1979, sciences, I: 249-261.

Farjon, A., 2005. A monograph of Cupressaceae and Sciadopitys.- 648 pp.; Kew (Royal Botanic Gardens, Kew).

Felix, J., 1894. Untersuchungen über fossile Hölzer. Zeitschrift der Deutschen Geologischen Gesellschaft, 46(1): $79-110$

Gray, S.F., 1822. A Natural Arrangement of British Plants (Nat. Arr. Brit. Pl.), 2: 222, 225.

Greguss, P., 1967. Fossil Gymnosperm woods in Hungary, from the Permian to the Pliocen. Akádemiai Kiádo, Budapest, 152 pp+93 pl.

Greguss, P., 1959. Holzanatomie der europäischen Laubholzer and Sträucher. Akádemiai Kiádo, 330 pp.+307 pl.

Greguss, P. (1969), Tertiary Angiosperm woods in Hungary. Akádemiai Kiádo, Budapest, 152 pp+93 pl.

Gros, J.P., 1983. Nouveau bois fossile d'Eggenburgian d'Autriche: Quercoxylon furwaldense n. sp. Révue générale de Botanique, 90: 43-80.

Gros, J.P., 1988. La dénomination des bois fossiles identifiés a des chênes. Bulletin Mensuel de la Societé. Linnéene, Lyon, 57: 250-260.

Gryc, V. \& Sakala, J., 2010. Identification of fossil trunks from Bükkábrány newly installed in the Visitor Centre of the Ipolytarnóc Fossils Nature Reserve (Novohrad - Nógrád Geopark) in Northern Hungary. Acta Universitatis Agriculturae et Silviculturae Mendelianae Brunensis, 58:117-122. http://ipolytarnoc.kvvm.hu/uploads/File/pdf/Sakala_a cta_bukkabrany.pdf

Hadziev, P. \& Mädel, E., 1962. Zwei neue Eichenholzer, aus dem Pliozän Bulgariens. Paläontologische Abhandlung, I/2: 107-122.

Hartig, T., 1848. Beiträge zur Geschichte der Pflanzen und zur Kenntnis der norddeutschen BraunkohlenFlora. Bot. Zeitung (Berlin), 6: 122-190.
Hofmann, E., 1929. Verkieselte Hölzer von der Vashegy(Eisenberg-) Gruppe Vasvárm. Ann. Sabariensis III, Szombathely Város Kultúregyes. Vasvárm. Múz. Évk. 3: 81-87.

Hofmann, E.,1952. Pflanzenreste aus dem Phosphoritvorkommen, von Prambachkirchen Im Oberöstereich, II Teil. Palaeontographica, Abt. B, Paläophytol. 92(3-6): 122-138.

Iamandei, E., Iamandei, S. \& Diaconu, F., 2011. Fossil woods in the collections of Drobeta-Tr. Severin $\mathrm{Mu}-$ seum. Acta Palaeontologica Romaniae, 7: 199-218. https://actapalrom.geo-paleontologica.org/

Iamandei, S. \& Iamandei, E. 1997. New Fossil Dicots in Pyrrhoclastics of Prăvăleni, Metalliferous Mountains. Acta Paleontologica Romaniae, 1:113-118, https://actapalrom.geo-paleontologica.org/

Iamandei S. \& Iamandei E.P., 2010. Trésors du fond des bois d'autrefois (Bois petrifiés du Musée National de Géologie de Bucarest). In : «Le Patrimoine Paléontologique - Des trésors du fond des temps». SaintMartin J.P. et al. (eds): 47-58; (C) 2010 GeoEcoMar, Bucarest.

Iamandei, S., Iamandei E., Frunzescu, D. \& Brănoiu. G., 2012. New petrified woods from the Curvature Carpathians. Romanian Journal of Earth Sciences, vol. 86(2): 67-89, http://rjes.igr.ro

Iamandei, S., Iamandei, E. \& Lupu, A.I., 2001. Some fossil woods from the Jassy Botanical Garden Collection. An. Sci., Univ. «A.I.Cuza», Geologie, XLVII: 267-274.

Iamandei, S., Iamandei, E. \& Lupu, A.I, 2008. Late Miocene oak trees from Solești-Vaslui (Fossil woods from the Jassy Botanical Garden Collection). Revue Roumaine de Geologie, Academie Roumaine, 44 : 57-61.

Iamandei, S., Iamandei, E., Bozukov, V. \& Tsenov, B., 2016. New Oligocene fossil woods from Rhodopes, Bulgaria. Acta Palaeontologica Romaniae, 12(2): 4765, https://actapalrom.geo-paleontologica.org/

Iamandei, S., Iamandei E. \& Stoia, T., 2020. Fossil woods from Bozovici. Romanian Journal of Earth Sciences, https://actapalrom.geo-paleontologica.org/ [in press].

Iamandei, S., Iamandei, E. \& Țibuleac, P., 2004. New fossil wood from Late Badenian of Prăvăleni, Metalliferous Mts. Analele Ştiinţifice ale Universităţii « A.I.Cuza», Iași, Geologie, 49-50/(2003-2004): 235247.

INSIDEWOOD 2004-onwards. Published on the Internet. http://insidewood.lib.ncsu.edu/search/ (accesed: December 8, 2015).

Jussieu, A. L., de, 1789. Genera plantarum: secundum ordines naturales disposita, juxta methodum in Horto regio parisiensi exaratam, anno M.DCC.LXXIV: 8082.

Koutecky, V. \& Sakala, J., 2015. New fossil woods from the Paleogene of Doupovske hory and Česke středohoři Mts. (Bohemian Massif, Czech Republic). Acta Musei Naturalis Pragae, Series B, Historia Naturalis, 71(3-4): 377-398.

Kraüsel, R., 1939. Ergebnisse der Forschungsreisen Prof. E. Stromers in den Wüsten Aegyptens, IV: Die Fossilen Floren Agyptens. Abhandlungen der Bayer- 
ischen Akademie der Wissenschaften, nov. ser., 17: 1-140.

Kräusel, R., 1949. Die fossilen koniferen-Hölzer (unter ausschluss von Araucarioxylon Krauss). II Teil. Kritische Untersuchungen zür diagnostic Lebender und Fossilen Koniferen-Hölzer. Palaeontographica Abt. B, 89(4-6): 83-203.

Lestiboudois T., 1826. Botanographie élémentaire, ou, Principes de botanique, d'anatomie et de physiologie végétale. Publisher: Paris-Lille-Roret-Vanackere, 559 pp.

Lupu, I.A., 1984. Étude d'un bois de chêne fossile provenant de l'interfleuve Siret-Moldova (Roumanie). Buletinul Grădinii Botanice, Universitatea "A.I. Cuza", Iaşi. (Volum Festiv "150 ani de la înfiinţarea Muzeului de Istorie Naturală"), pp. 369-372,

Mantzouka, D., Sakala, J., Kvaček, Z. \& Karakitsios, V., 2013. Palaeobotanical study of Polichnitos region, Southern part of Lesbos island, Greece - preliminary results on Angiosperm wood. (Proceedings of the 13th International Congress, Chania, Sept. 2013). Bulletin of the Geological Society of Greece, XLVII(1): 204-215

Meijer, J.I.F., 2000. Fossil woods from the Late Cretaceous Aachen Formation. Review of Palaeobotany and Palynology, 112: 297-336.

Müller-Stoll, W.R. \& Mädel, E., 1957. Über tertiäre Eichenholzer aus dem pannonischen Becken. Senckenbergiana lethaea, 38(3-4): 121-168.

Nagy, F. \& Mârza, I., 1967. Magnolioxylon transilvanicum sp. n. in cineritele de la Prăvăleni, Brad. Analele Universităţii Bucureşti, St. Nat., Geol.Geogr., 16(1): 97-102, [in Romanian].

Page, V.M., 1968. Angiosperm wood from the Upper Cretaceous of Central California: Part II. American Journal of Botany, 55: 168-172.

Petrescu, I., 1976. Asupra unor lemne de stejari (Quercoxylon) din Neogenul de la sud de Câmpulung (jud. Argeş). Contribuţii Botanice, Univ. "BabeşBolyai”, Grădina Botanică. Cluj-Napoca: 179-185, [in Romanian].

Petrescu, I. (1978), Studiul lemnelor fosile din Oligocenul din nord-vestul Transilvaniei. Mémoires (IGR), XXVII: 113-184, 74 pl. [in Romanian].

Petrescu, I. \& Nuţu A., 1970. Alte tipuri de lemne din Miocenul superior de la Prăvăleni-Brad. Sargetia (Acta Musei Devensis), sr. Sc. Nat., VII: 253-258, [in Romanian].

Petrescu I. \& Nuţu A., 1971. Asupra unor noi aflorimente de lemne fosile din Miocenul superior al munților Metaliferi. Sargetia (Acta Musei Devensis), series Sc. Nat., VIII: 9-15. [in Romanian].

Petrescu, I. \& Nuţu, A., 1972. Asupra unui lemn de Icacinoxylon Shilkina în Miocenul superior de la Prăvăleni - Brad. Sargetia (Acta Musei Devensis), sr. Sc. Nat., IX: 77-79, 2pl. , [in Romanian].

Petrescu, I. \& Dragastan, O., 1972. Asupra unor lemne de Icacinoxylon Shilkina din Oligocenul de la TelegaPrahova. Studii si cercetări de geologie, geofizică, geografie, Geologie, 2(11): 445 -451, [in Romanian].

Poole, I., Davies, K.L. \& Wilkinson, H.P., 2002. A review of the platanaceous woods from the Eocene par- atropical rainforest of south-east England. Botanical Journal of the Linnean Society, 139: 181-191.

Prakash U., Březinová, D. \& Bůžek, C., 1971. Fossil Woods from Doupovské hory and České středohoří Mountains, in Northern Bohemia. Palaeontographica Abt. B, 133(1-6): 103-128.

Privé-Gill, C. (1975), Étude de quelques bois fossile de chênes tertiaires du Massif Central, France. Palaeontographica Abt. B, 153(4-6): 119-140.

Roy, S.K. \& Stewart, W.N., 1971. Oligocene woods from the Cypress Hills Formation in Saskatchewan, Canada. Canadian Journal of Botany, 49: 1867-1877.

Sakala, J., Rapprich, V. \& Pécskay, Z., 2010. Fossil angiosperm wood and its host deposits from the periphery of a dominantly effusive ancient volcano (Doupovské hory Volcanic Complex, Oligocene-Lower Miocene, Czech Republic): systematics, volcanology, geochronology and taphonomy. Bulletin of Geosciences, 85(4): $\quad 617-629$. http://web.natur.cuni.cz/ugp/main/staff/sakala/04divers/papers/1196_sakala.pdf

Srivastava, R. \& Suzuki, M., 2001. More fossil woods from the Palaeogene of northern Kyushu, Japan. IAWA Journal, 22(1): 85-105.

Schoch, W., Heller, I., Schweingruber, F.H. \& Kienast, F., 2004. Wood anatomy of central European Species. Online version: www.woodanatomy.ch

Schönfeld, E., 1958. Eine Magnoliaceae als Treibholz im marinen Oberoligozän der Niederheineschen Bucht. Fortschrungen in Geologie, Rheinland und Westfalen, 1: 169-178.

Schweingruber, F., H., 1990. Anatomie europäischer Hölzer (Anatomy of European woods). Verlag Paul Haupt, Bern, Stuttgart,1-765,

Selmeier, A., 1971. Ein verkieseltes Eichenholz, aus jungtertiären Schichten Niederbayerns (Aidenbach). Mitteilungen der Bayerischen Staatssammlung für Paläontologie und Historische Geologie, 11: 205-222.

Selmeier, A., 1996. Tertiary Platanus woods from the northalpine Molasse basin (Austria, Germany). Mitteilungen der Bayerischen Staatssammlung für Paläontologie und Historische Geologie, 36: 157-183.

Selmeier, A. (1997), Tertiare Lithocarpus Holzer aus Bad Abbach (Bayern, Suddeutschland). Mitteilungen der Bayerischen Staatssammlung für Paläontologie und Historische Geologie, 37: 119-134.

Srivastava, R. \& Suzuki, M., 2001. More fossil woods from the Palaeogene of Northern Kyushu, Japan. IAWA Journal, 22: 85-105.

Starostin, G. \& Trelea, N., 1984. Contributions á l'étude du genre Quercus du Sarmatien de Moldavie (Roumanie). Buletinul Grădinii Botanice, Univ. "A.I. Cuza", Iaşi. (Vol. Fest. "150 ani de la înfiinţarea Muzeului de Istorie Naturală"): 317-322, 1 pl.

Stockmans, F., 1936. Végétaux éocènes des environs de Bruxelles. Mémoires de la Société royale d'Histoire Naturelle de Belgique, 76: 1-56.

Suzuki, M. \& Ohba, H., 1991. A Revision of Fossil Woods of Quercus and Its Allies, in Japan. Journal of Japanese Botany, 66: 255-274.

Süss, H. 1960. Ein Monimiaceen-Holz aus der oberen Kreide Deutschlands, Hedycaryoxylon subaffine (Va- 
ter) nov. comb. Senckenbergiana Lethaea, 41: 317330.

Süss, H., 1971. Über das Vorkommen von Platanen und platanenähnlichen Holzresten im Miozän der Ungarischen VR. Geologie, 20: 74-81.

Süss, H., 1980. Ein Platanenholz aus dem Untereozän der Greifswalder Oie Platanoxylon cohenii (Schuster) comb. nov. Schriftenreihe Geologischen Wißenschaften Berlin 16: 401-416.

Süss, H. 1986. Untersuchungen über fossile Buchenhölzer. Beiträge zu einer Monographie der Gattung Fagoxylon Stopes \& Fujii. Feddes Repertorium, 97: 61-183.

Süss, H., 2007. Holzfossilien der Morphogattung Spiroplatanoxylon gen. nov. aus dem Tertiär von Europa und Vorderasien. Feddes Repertorium, 118(1-2): 119.

Süss, H. \& Müller-Stoll, W.R., 1977. Untersuchungen uber fossile Platanenhölzer. Beiträge zu einer monographie der Gattung Platanoxylon Andreánszky. Feddes Repertorium, 88:1-62.

Suzuki, M. \& Ohba, H., 1991. A Revision of Fossil Woods of Quercus and Its Allies, in Japan. Journal of Japanese Botany, 66: 255-274.

Süss H. \& Velitzelos, E., 1998. Thujoxylon antissum sp. nov, ein fossiles Wurzelholz aus tertiären Schichten des Versteinerten Waldes von Lesbos, Griechenland. Feddes Repertorium 109(5-6): 341-350. http://onlinelibrary.wiley.com/doi/10.1002/fedr.19981 090502/abstract

Sweet, R., 1826. Sweet's Hortus Britannicus: or a catalogue of plants cultivated in the gardens of Great Britain, arranged in natural orders, p. 372, London.

The Plant List., 2013. Version 1.1. Published on the Internet; http://www.theplantlist.org/ (accessed at 01.10.2016).

Takahashi, K. \& M. Suzuki. 2003. Dicotyledonous fossil wood flora and early evolution of wood characters in the Cretaceous of Hokkaido, Japan. IAWA Journal, 24: 269-309.

Továrková, I., Gryc, V. \& Sakala, J., 2011. First anatomically characterized wood from the Tertiary of Moravia: Spiroplatanoxylon from the area of Austerlitz (Southern Moravia, Czech Republic). Acta Universitatis Agriculturae et Silviculturae Mendelianae Brunensis 59: 367-372. http://web.natur.cuni.cz/ugp/main/staff/sakala/04divers/papers/45_tovarkova_11_6_aj.pdf

Unger, F., 1847. Chloris protogaea. Beiträge zur Flora der Vorwelt, Leipzig, 8-10: 93-149.
Van der Burgh, L., 1973. Hölzer der niederrheinischen Braunkohlenformation, 2. Hölzer der Braunkohlengruben "Maria Theresia" zu Herzogenrath "zukunft west"zu Eschweiler und "Victor (Zülpich Mitte), zu Zülpich. Nebst einer systematisch-anatomischen Bearbeitung der gattung Pinus L. Review of Palaeobotany and Palynology, Elsevier Science Publishers B.V., 15(2-3):73-275.

Vaudois, N. \& Prive, C., 1971. Revision de bois de $\mathrm{Cu}-$ pressaceae. Palaeontographica Abt. B, 134(1-3): 6186, Stuttgart.

Vogellehner, D., 1967. Zur Anatomie und Phylogenie de Mesozoischer Gymnospermenholzer, 7: Prodromus zu einer Monographie de Protopinaceae. I. Die Protopinoiden Holzer des Trias. Palaeontographica Abt. B, 121(1-3): 30-51.

Vogellehner, D., 1968. Zur Anatomie und Phylogenie de Mesozoischer Gymnospermenholzer, 7: Prodromus zu einer Monographie de Protopinaceae. II. Die Protopinoiden Holzer des Jura. Palaeontographica Abt. B, 124(4 -6): 125-162.

Watson, L., \& Dallwitz, M.J., 1992. The families of flowering plants: descriptions, illustrations, identification, and information retrieval. Version: 19th October 2016. Onwards: http://delta-intkey.com/angio/

Wheeler, E.A. 2011. InsideWood - a web resource for hardwood anatomy. IAWA Journal, 32(2): 199-211.

Wheeler, E.A., Baas, P. \& Gasson, P.E., 1989. IAWA List of Microscopic Features for Hardwood Identification. IAWA Bulletin n. s., 10(3): 219 - 332, Leiden.

Wheeler, E.A. \& Baas, P., 1991. A survey of the fossil record for dicotyledonous wood and its significance for evolutionary and ecological wood anatomy. IAWA Journal, 312: 275-318.

Wheeler, E.A., McClammer, J., \& LaPasha, C.A., 1995. Similarities and differences in dicotyledonous woods of the Cretaceous and Paleocene, San Juan Basin, New Mexico, USA. IAWA Journal, 16(3): 223-254.

Wheeler, E.A., Scott, R.A. \& Barghoorn, E.S., 1977. Fossil dicotyledonous woods from Yellowstone National Park, I. Journal of the Arnold Arboretum, 58(3): 280306.

Wheeler, E.A. \& Manchester S.R., 2002. Woods of the Eocene Nut Beds flora, Clarno Formation, Oregon, USA. IAWA Journal, Supplement 3: 1-188.

Zalewska, Z., 1953. Treciorzedowe szczatki drewna z Turowa nad Nysa Luzycka. Acta Geologica Polonica, III(4): 481-543, $10 \mathrm{pl}$. 